\title{
Brucellosis presenting with pancytopenia due to hemophagocytic syndrome
}

\author{
Hemofagositik sendroma bağlı pansitopeni ile başvuran bruselloz olgusu
}

\author{
Ela Erdem, Yıldız Yıldırmak, Nurşen Günaydın \\ Department of Pediatrics, Şişli Etfal Education and Research Hospital, Istanbul, Turkey
}

\begin{abstract}
Reactive hemophagocytic syndrome is clinically characterized by fever, hepatosplenomegaly, pancytopenia, and coagulopathy, and is histologically characterized by excessive proliferation and activation of histiocytes or macrophages. It can occur with systemic infections, immunodeficiency, or underlying malignancy. Brucellosis is one of the rare causes of hemophagocytosis. Herein we report an 11-year-old male with pancytopenia due to hemophagocytosis during the course of brucellosis that responded favorably to therapy. Although rare, hemophagocytosis should be considered as a possible cause of pancytopenia in patients with brucellosis, especially in regions where brucellosis is frequently encountered. (Turk J Hematol 2011; 28: 68-71)
\end{abstract}

Key words: Brucellosis, pancytopenia, hemophagocytosis

Received: June 05, 2009

Accepted: September 18, 2009

\section{Özet}

Reaktif hemofagositik sendrom klinik olarak ateş, karaciğer ve dalak boyutlarında artış, pansitopeni ve pıhtılaşma bozuklukları; histolojik olarak da histiyosit ya da makrofajların artmış proliferasyon ve aktivasyonları ile karakterizedir. Sistemik hastalıklar, immun yetmezlikler ve altta yatan malignitelerle birlikte olabilir. Brusella, hemofagositozun nadir nedenlerinden biridir. Brusellanın sık görüldüğ̈̈ ülkelerde pansitopenisi olan hastalarda hemofagositozu hatırlatmak amacı ile, brusella seyri sırasında hemofagositoza bağlı pansitopenisi olan, uygun tedavi sonrası iyileşen 11 yaşında bir erkek hasta sunulmaktadır. (Turk J Hematol 2011; 28: 68-71)

Anahtar kelimeler: Brusella, pansitopeni, hemofagositoz

Geliş tarihi: 5 Haziran 2009

Kabul tarihi: 18 Eylül 2009 


\section{Introduction}

Hemophagocytic lymphohistiocytosis (HLH) is an unusual syndrome characterized by acute onset of fever, hepatosplenomegaly, lymphadenopathy, and jaundice, along with the pathological findings of hemophagocytosis (phagocytosis of erythrocytes, leukocytes, platelets, and their precursors by macrophages) in bone marrow and other tissues. Although de novo HLH can also be seen, it often occurs in the setting of another disorder - usually in association with malignant, infections, or autoimmune diseases that are prominently linked with Epstein-Barr virus (EBV) infection [1]. Non-viral infections and bacterial infections, including tuberculosis, are other major causes [2]. Fungal and parasitic causes of HLH have also been reported $[3,4]$. Brucellosis is one of the rare causes of hemophagocytosis. Herein we present a case of pancytopenia due to hemophagocytosis during the course of brucellosis.

\section{Case Report}

An 11-year-old male presented to our hospital with symptoms of fever, loss of appetite, and headache, which began 5 days earlier. The patient's parents were not consanguineous. His height was $138 \mathrm{~cm}\left(10^{\text {th }}-25^{\text {th }}\right.$ percentile $)$ and weight was $26 \mathrm{~kg}$ ( $3^{\text {rd }}-10^{\text {th }}$ percentile). His general health status was moderately good and neurological findings were normal. In physical examination the liver and spleen were $8 \mathrm{~cm}$ and $10 \mathrm{~cm}$, respectively, and palpable below the costal margin of the midclavicular line, with multiple bilateral inguinal lymphadenopathies. He was diagnosed with pancytopenia based on the following laboratory findings: hemoglobin: $7.3 \mathrm{~g} \mathrm{dL}$; mean corpuscular volume: $77 \mathrm{fL}$; white blood cell count: $2600 \mathrm{~mm}^{3}$ (granulocyte: 900 $\mathrm{mm}^{3}$ ); platelet count: $85,000 \mathrm{~mm}^{3}$; SGOT: $65 \mathrm{U} \mathrm{L}^{1}$; SGPT: $16 \mathrm{U} \mathrm{L}$; LDH: $1733 \mathrm{U} \mathrm{L}^{1}$; cholesterol: $155 \mathrm{mg} /$ dL; triglycerides: $345 \mathrm{mg} / \mathrm{dL}$; HDL: $13 \mathrm{mg} / \mathrm{dL}$; VLDL: $73 \mathrm{mg} / \mathrm{dL}$; LDL: $69 \mathrm{mg} / \mathrm{dL}$; total bilirubin: $0.5 \mathrm{mg} / \mathrm{dL}$; total protein: $5.3 \mathrm{~g}$ dL; albumin: $2.5 \mathrm{~g} \mathrm{dL}$; ferritin: $3167 \mathrm{ng} / \mathrm{mL}$; prothrombin time: $14.1 \mathrm{sec}$; prothrombin activity: 60\%; partial thromboplastin time: 29.3 sec; fibrinogen: $155 \mathrm{mg} / \mathrm{dL}$. Burr cells and cells resembling sickle cells were observed in peripheral smear.
In order to exclude malignancy as a cause of pancytopenia, bone marrow aspiration was performed, which showed the presence of hemophagocytes (Figure 1). Based on the clinical, laboratory (pancytopenia, hypertriglyceridemia, hypofibrinogenemia, and elevated ferritin level), and bone marrow aspiration findings, the patient was diagnosed with secondary hemophagocytic syndrome. Serological markers were examined for EBV, cytomegalovirus, hepatitis B, parvovirus, Salmonella, and Brucella. Wright agglutination test results were positive, with a titer of $1 / 2560$. Immediately following the bone marrow biopsy and culture to confirm the diagnosis, a course of antibiotic treatment was initiated (oral doxycycline $200 \mathrm{mg} /$ day for 6 weeks and intravenous gentamycin $5 \mathrm{mg} / \mathrm{kg} /$ day for 2 weeks). Blood and bone marrow cultures remained sterile.

Examination of the biopsy specimens showed that the bone marrow was normocellular and contained macrophages that phagocytized the lymphoid and erythroid elements. After 1 week of antibiotic treatment the patient was afebrile. At the end of the third week of doxycycline treatment the patient's white blood cell count was $2480 \mathrm{~mm}^{3}$ (granulocyte: $1680 \mathrm{~mm}^{3}$ ), hemoglobin was $9.7 \mathrm{~g} \mathrm{dL}$, and platelet count was $175,000 \mathrm{~mm}^{3}$. Six months after treatment began the patient's white blood cell count was $6640 \mathrm{~mm}^{3}$, neutrophils was $3600 \mathrm{~mm}^{3}$, hemoglobin was $13.8 \mathrm{~g} \mathrm{dL}$, and platelet count was $187,000 \mathrm{~mm}^{3}$. The patient remained symptom-free with progressive decrease in the titers of Wright agglutination test.

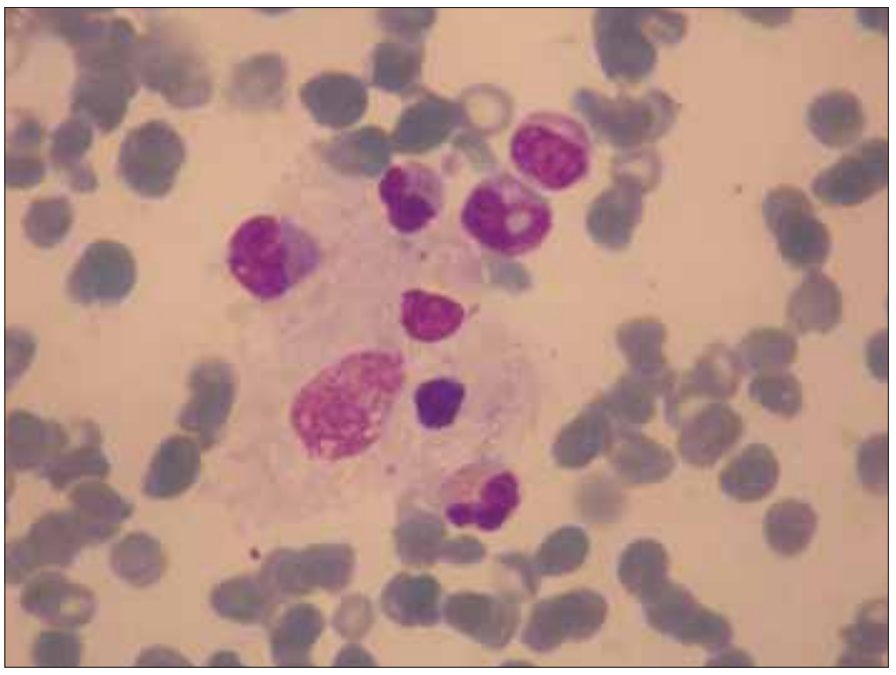

Figure 1. Bone marrow smear demonstrating hemophagocytosis by a large histiocyte (Giemsa stain, 1000×) 
Written informed consent was obtained from the patient's family.

\section{Discussion}

HLH was first described by Scott in 1939 [5] and has since been associated with a variety of viral, bacterial, fungal, and parasitic infections, as well as collagen-vascular diseases and malignancies - particularly T-cell lymphomas. This diversity has led to the suggestion that HLH secondary to an underlying medical illness should be regarded as reactive hemophagocytic syndrome. Both sporadic and familial cases of HLH are often precipitated by acute infections, and HLH may mimic infectious illnesses such as overwhelming bacterial sepsis, which emphasizes the importance of the association between HLH and infection. As such, a better understanding of the pathophysiology of HLH may clarify the interaction between the immune system and infectious agents. Brucellosis is among the rare causes of secondary HLH, in which hematological alterations are common and pancytopenia is observed in $6 \%$ of patients [6].

Examination of bone marrow aspiration specimens shows normo-, hyper-, or hypocellularity [7]. In addition to pancytopenia, severe disorders including hemophagocytic syndrome - have also been described in association with brucellosis. Although the mechanism of hemophagocytosis induction in cases of brucellosis is not well understood, immune system derangement, with defective T-cell functioning, T-cell and monocyte hyperactivation, hypercytokinemia, and selective deficiency in cellular cytotoxicity has been reported. [8]

Macrophages can be activated when they come into contact with foreign substances such as bacteria. This activation, in turn, can cause hemophagocytosis when macrophages come into contact with red blood cells, white blood cells, and platelets, leading to the clinical symptoms in the same nonspecific way as when they come into contact with foreign organisms. Although the precise mechanism remains unclear, 1 currently accepted theory suggests the role of perforin and natural killer cells in HLH subtypes [9]. Patients with perforin deficiency may have impaired defenses against intracellular pathogens, which is also critically important to the mechanism of primary HLH. Decreased natu- ral killer cell activity results in increased T-cell activation, immediately followed by cytokine production, which leads to an inflammatory reaction, and extensive damage and associated symptoms [10].

Hemophagocytic syndrome is less common in children than in adults. A search of the literature showed that there are only 3 published reports of hemophagocytosis secondary to brucellosis in children [11-13]. Hemophagocytic syndrome in children should be differentiated from familial HLH, which is characterized by early onset, a higher prevalence of parental consanguinity, and an association with immune deficiencies, such as ChediakHigashi syndrome, Griscelli syndrome, and X-linked lymphoproliferative syndrome. Both conditions can be triggered by infections or other stimuli; however, most patients with secondary HLH have no underlying immune deficiency. Brucellosis associated with pancytopenia and evidence of reactive hemophagocytosis were first reported by Zuazu et al. in 1979 [14]. The presented case had fever, hepatosplenomegaly, and pancytopenia. Pancytopenia associated with brucellosis is attributed to hypersplenism, hemophagocytosis, and granulomatous lesions of the bone marrow, which is usually hypercellular $[13,15,16]$. In the present case we think that hemophagocytosis was responsible for pancytopenia.

As isolation of the organism is difficult, serological tests are used for the routine diagnosis of brucellosis in most cases and the agglutination test is used as the principal test. When brucellosis is suspected in patients with negative cultures, rising agglutinin titers over 1:160 are considered diagnostic. [17] With the availability of effective therapy the mortality rate associated with brucellosis has declined. In some cases, intravenous immunoglobulin is used for treatment, which results in remission in adults and older children, particularly those with an underlying immune dysfunction; however, the role of this treatment in cases of hemophagocytosis is unclear [18]. The presented case recovered after antimicrobial treatment, without the need for intravenous immunoglobulin.

Brucellosis must be considered in the differential diagnosis of malignant or benign diseases associated with hemophagocytosis, especially in geographic areas where brucella infection is common. The pathogenesis of pancytopenia in brucellosis is not clear, but appears to be multi-factorial. Although 
rare, hemophagocytosis should be considered a possible cause of pancytopenia in patients with brucellosis.

\section{Conflict of interest statement}

The authors declare that there are no conflicts of interest. None of the authors have a financial or proprietary interest in the case report preparation. All of the authors have been duly credited.

\section{References}

1. Janka G, Stadt U: Familial and acquired hemophagocytic lymphocytic lymphohistiocytosis. Hematology 2005; 1:82-8. [CrossRef]

2. Lee SW, Wang CY, Lee BJ, Kuo CY, Kuo CL. Hemophagocytic Syndrome in Miliary Tuberculosis Presenting with Noncaseating Granulomas in Bone Marrow and Liver. JFMA 2008;107:495-9.

3. Numata K, Tsutsumi H, Wakai S, Tachi N, Chiba S. A child case of hemophagocytic syndrome associated with cryptococcal meningitis. J Infect 1998;37:118-9. [CrossRef]

4. Kocak N, Eren M, Yuce A, Gumruk F. Hemophagocytic syndrome associated with visceral leishmaniasis. Indian Pediatr 2004;41:605-7.

5. Scott R, Robb-Smith A. Histiocytic medullary reticulosis. Lancet 1939;2:194-8.

6. Ajlouni YM, Shaker K: Hematological manifestations of human brucellosis. QMJ 1998;2:41-3.

7. Yildirmak Y, Palanduz A, Telhan L, Arapoglu M, Kayaalp $\mathrm{N}$. Bone marrow hypoplasia during brucella infection. J Pediatr Hematol Oncol 2003;25:63-4. [CrossRef]

8. Henter JI, Arico M, Elinder G, Imashuku S, Janka G.
Familial hemophagocytic lymphohistiocytosis. Primary hemophagocytic lymphohistiocytosis. Hematol Oncol Clin North Am 1998;12:417-33. [CrossRef]

9. Risma KA, Frayer RW, Filipovich AH, Sumegi J. Aberrant maturation of mutant perforin underlies the clinical diversity of hemophagocytic lymphohistiocytosis. J Clin Invest 2006;116:182-92. [CrossRef]

10. Arico M, Danesino C, Pende D, Moretta L. Pathogenesis of haemophagocytic lymphohistiocytosis. $\mathrm{Br} \quad \mathrm{J}$ Haematol 2001;114:761-69. [CrossRef]

11. Karakukcu M, Patiroglu T, Ozdemir MA, Gunes T, Gumus $\mathrm{H}$, Karakukcu C. Pancytopenia, a rare hematologic manifestation of brucellosis in children. J Pediatr Hematol Oncol 2004;26:803-6.

12. Ullrich CH, Fader R, Fahner JB, Barbour SD. Brucellosis presenting as prolonged fever and hemophagocytosis. Am J Dis Child 1993;147:1037-8.

13. Al-Eissa YA, Assuhaimi SA, Al-Fawaz IM, Higgy KE, Al-Nasser MN, Al-Mobaireek KF. Pancytopenia in children with brucellosis: clinical manifestations and bone marrow findings. Acta Haematol 1993;89:132-6. [CrossRef]

14. Zuazu JP, Duran JW, Julia AF. Hemophagocytosis in acute brucellosis. N Engl J Med 1979;301:1185-6. [CrossRef]

15. Akdeniz H, Irmak H, Seckinli T, Buzgan T, Demiröz AP. Hematological manifestations in brucellosis cases in Turkey. Acta Med Okayama 1998;52:63-5.

16. Martin-Moreno S, Soto-Guzman O, Bernaldo-de-Quiros J, Reverte-Cejudo D, Bascones-Casas C. Pancytopenia due to hemophagocytosis in patients with brucellosis: a report of four cases. J Infect Dis 1983;147:445-9.

17. Moyer NP, Holcomb LA, Hauslert WJ. Brucella. In: Balows A, ed. Manual of Clinical Microbiology. Washington: American Society for Microbiology, 1991:457-61.

18. Gill D, Spencer A, Cobcroft R. High dose gamma-globulin therapy in the reactive hemophagocytic syndrome. Br J Haematol 1994;88:204-6. [CrossRef] 